マイナス面を補う以上のプラス面がある。

質問 （福岡 森山）撮影条件の入力は?

答 (鹿児島 堀江) 単一の申し込みの場合は, 入力し ておけば可能であるが， $2 \sim 3$ 種類の申し込みでは困難 なため, 手書きである.

質問 （福岡 森山）フィルムラベルおよびフィルム袋 の記入法は？

答 (鹿児島 堀江)明室化処理でフィルムに焼き付け ている。袋は手書きである。

答 (鹿児島 野上) 薬剤部でシール作製を行っている が, コスト高で, 専用機器の購入, 打出し時間等を考慮 すると, 現時点では, 否定的で実施していない。

患者待ち時間解消, スムーズな検査実施等医療サービ ス向上のため, 電算化は医事業務のみにとどまらず，検 查予約システムへと広がってきた。このシステム構築の ためには, 鹿大, 野上も発表しているように, 全病院的 意識が必要である．また, 宮崎, 稲津は電算化で患者と の対話の減少に不安があると指摘した。

情報管理は, 放射線診療では, 申し込み, 予約, 診断, フィルム保管の一体化を考え，一放射線部の問題でなく， 医療情報のシステム化の一環として考える時期にきてい る.

RI

座長 春田隆昌（大分医科大学附属病院）

29. マルチチャンネル型シンチレーション・カウンタ検 出部の庶蔽能力が測定值に与える影響

国立福岡中央病院放射線科

○秋永不二夫・金城睦男・池田尋隆

山本浩二・田代浩一・塩谷佳三

鴐海良彦

九州大学医療技術短期大学部 長 哲二

RIA 法による検查件数は年々増加しており, 複数の検 出部を持つマルチチャンネル型のシンチレーション・カ ウンタが普及してきている，当院においても，4チャン ネル型のカウンタを使用しているが, 高計数率の試料測 定時に他試料測定值に影響を与えており, 高感度 TSH 測定を開始したので，その影響度について検討を行った。 I-125 溶液で倍々希釈法により数種の試料を作成し，マ ルチチャンネル型シンチレーション・カウンタで測定を 行い, 近隣試料への影響度を検討した. 高感度 TSH の場 合, $0.01 \sim 0.02 \mu \mathrm{U} / \mathrm{m} l$ の誤差に相当するため, 測定に際 しては十分な配慮が必要と思われる。

30. GCA-90B を用いた矢状方向サンプリングの画像の 検討
国立療養所再春荘病院 ○杉浦龍登

熊本大学医療技術短期大学部放射線学科.

吉田日出輝

国立療養所再春荘病院放射線科

河野 孟・米村政昭

熊本県宇土保健所 魚住敏郎

大分医科大学附属病院放射線科 船越 猛

〔目的〕 1) SPECT 像でできるだけ時間を短縮

a) 画質の向上の検討

b) 患者負担の軽減

2） ${ }^{123} \mathrm{I}-\mathrm{IMP}$ の使用経験と臨床例報告

〔方法〕東芝 GCA-90 B 角型ガンマカメラを用いて 頭部の ECT を行う場合ガンマカメラを体軸に垂直な方 向で $360^{\circ}$ 回転を行いデー夕を収集する方法とカメラを 頭部矢状方向にPOST から ANTに $180^{\circ}$ 回転させ収集 する方法について次のような画像の評価を行う. ECT フ アントムを用いて均一補性, スムージング, フィルタを 変え, このときの画像評価を行う.

評価法 径の異なる各 lesion の描出程度を 3 段階表 示

分解能, 各 lesion の中心で切った profile の FWHM を表示

今回特にMTF の測定結果も加える.

〔発表の意義・新しい点等〕1）GCA-90B 角型で $180^{\circ}$ 回転でデータ収集すると検查時間が $360^{\circ}$ 回転でデータ 収集の半分の時間で，少なくとも同等の画像が得られる。

2）データ収集時間が $360^{\circ}$ 回転収集の場合，60分と長 時間なため ${ }^{123} \mathrm{I}-\mathrm{IMP}$ のように半減期が 13 時間と短いも のには, 最初のフレームと最後のフレームの計数率の差 が大きくなり画像の低下を来す可能性がある.

3）画像評価を 2 次フーリエを用いた MTFで行って みる。

\section{1. 肺吸入シンチグラフィーの使用経験}

産業医科大学病院 ○田中幸枝・高橋里美

CIS 製 MEDI-61 のエアロゾル発生装置に酸素 61 / min を送り, 安静呼吸で10分間吸入させると, RI の肺内 放射能カウントはほぼ直線的に増加している. 肺内沈着 率は2.91\%だった。次に被検者29名を正常群と I〜V群 の疾患別に分け，右肺クリアランスの定量的検討を行っ た. 吸入直後の末梢への RI 到達度で正常群は疾患 4 群 より高く肺内に均一分布していることがわかる，また約 1.5 時間後と 3 時間後の経時的変化は, 正常群は両者の値 に差がないが, 気管支拡張例の第 II 群は 0.1 以上低くなり 喀出が行われている，以上よりイメージに定量的評価を 